\title{
80. narozeniny prof. PhDr. Zdenky Rusínové, CSc.
}

Paní profesorka Zdenka Rusínová oslaví v letošním roce významné životní jubileum. Na stránkách časopisu Linguistica Brunensia je třeba ji představit snad jen nejmladší generaci, která již nezažila její přednášky a semináře z české morfologie a slovotvorby a která nezná paní profesorku takovou, jak ji známe my: milou, veselou paní s trochou zdravé skepse provázené tím nezapomenutelným nakloněním hlavy a pohledem trošku zešikma.

A přesto ji i ti, kteří ji po odchodu na zasloužený odpočinek a za milovanými vnuky již neměli př́ležitost zažít jako učitelku, znají zajisté jako autorku základní studijní literatury bohemistických studií, jako autorku řady hesel Encyklopedického slovníku češtiny, Nového encyklopedického slovníku češtiny i jako autorku oddílu Morfologie v Příruční mluvnici češtiny.

Paní profesorka Rusínová se narodila 13. června 1939 v Ostravě. Vystudovala na brněnské univerzitě obory český a ruský jazyk. Na začátku své profesní dráhy se věnovala dialektologii se zvláštním zřetelem k morfologickým a slovotvorným aspektům. Po studiu nastoupila jako asistentka Katedry českého a slovenského jazyka a literatury na rodné univerzitě (tehdejší UJEP v Brně). Vzhledem k nekompromisním politickým postojům v době bývalého režimu byla paní profesorce dovolena habilitace až po sametové revoluci v roce 1992. O pět let později byla jmenována univerzitní profesorkou oboru český jazyk. V letech 1996-1999 stála v čele Ústavu českého jazyka FF MU. Od roku 1990 do roku 1994 vykonávala funkci místopředsedkyně Akademickému senátu FF MU. V letech 1994-1995 byla proděkankou FF MU, v letech 1994-2000 členkou vědecké rady FF MU.

I po odchodu do penze paní profesorka neztratila kontakt se studenty. Ti iniciovali v roce 2011 v nakladatelství Host vydání knihy Pokušení struktury, druhého svazku edice Studie osobností brněnské lingvistiky. Svazek obsahuje habilitační spis Zdenky Rusínové a jsou v něm přetištěny její významné časopisecké studie.

V časopise Host paní profesorka dodnes uveřejňuje v rubrice Glosy svoje úvahy o jazyce.

Naposled jsem paní profesorku viděla přednášet v roce 2014 v Kabaretu U Špačků v rámci cyklu s konspirativně laděným názvem Podzemní univerzita. Přednáška „Jak mluvíme a co tím děláme“ byla taková jako paní profesorka - stále svěží, zajímavá s přehledem i nadhledem.

Paní profesorka je s námi v kontaktu stále - loni v září zasedla v komisi při obhajobě disertační práce své (jak se zapřísahá) poslední doktorandky.

Milá Zdenko, přeji Ti do dalších let, aby Ti Tvůj životní elán, který jsme na Tobě vždy obdivovali a který už nám někdy začíná docházet, vydržel a abys se svými drahými prožila ještě mnoho štastných chvil. Máme Tě rádi. 


\section{Klára Osolsobě}

\section{Department of Czech Language}

Faculty of Arts, Masaryk University

Arna Nováka 1, 602 oo Brno

Czech Republic

osolsobe@phil.muni.cz 